\title{
CHANGE DYNAMICS AND RELATED LEADERSHIP COMPETENCIES
}

\author{
C VON ECK \\ claudelle@iiasa.org.za \\ A VERWEY \\ Department of Human Resources Management \\ University of Johannesburg
}

\begin{abstract}
The purpose of this study was to develop a framework containing a set of leadership competencies required for major change types. It also compared the views of managers and employees on the importance of these competencies as well as the degree to which managers display the competencies. Ten leaders participated in the qualitative phase of the study and 60 managers and 74 employees responded to the survey. The major outcomes of the study included the competency framework as well as the competencies where statistically significant differences between the managers' and employees' views on, a) the degree to which the managers display the competencies as well as b) the importance assigned to the competencies, were found.
\end{abstract}

Key words: Leadership, Change, competencies, Followers, complexity

Management experts agree that leadership could be the number one strategic concern of businesses in the 21st century (Lussier, 1997). This is echoed by Kets de Vries (2001) who states that the effectiveness of an organisation's employees, who are in leadership positions, will determine how the organisation will perform. Furthermore, this performance is impacted upon by the fact that organisations are faced with a number of critical issues. These issues range from changes in societal values to changes in investor focus (Higgs, 2003).

Leadership in the face of change is therefore a topic of crucial concern to all organisations in the present turbulent business environment. This is also due to the fact that the impact of change increasingly leads to the demise of many businesses. Some of the major challenges that accompany change include:

- The constantly changing environment has created an unpredictable future as the marketplace has lost its predictability (Rabey, 2006); and hence

- The unpredictability of change. Not being able to predict what type of change the organisation is going to be faced with next (Grieves, 2000);

- The uncertainty around the outcome of the change (Grieves, 2000). There is no clear relationship between the scale of the change and the scale of its impact within an organisation (French, 2001); and

- The risk of failure. Many change initiatives undertaken by organisations are, even with the best intentions, often destined for failure in some point in implementation. Various surveys have shown that a very low percentage of change programmes are successful (Siegel et al, 1996).

Adding to the complexity created by these challenges that the leader has to contend with, the leader must also understand how to lead employees through the uncertainty that accompanies change. A reasonable deduction that can therefore be made is that leaders require competencies that will enable them to deal with the new world of rapid change and its unique challenges. The skills that may have worked in a more stable environment are inadequate in the new era of uncertainty and rapid change (Marquardt, 2000).

\section{Leadership}

Leadership defines what the future should look like and then aligns and inspires people to realise the vision (Kotter, 1996). In terms of organisations, it refers to the process of influencing employees to work toward the achievement of organisational objectives (Lussier, 1997). The alignment, inspiration and influence referred to by Kotter and Lussier are rooted in the human need for leadership (Kets de Vries, 2001). People want guidance about where to go and how to get there.

The primary task of leadership is therefore to create a context that calls forth and taps into the emergent potential of the organisation (Pascale, 1999). In this context, Senge (1999) defines leadership as the capacity of a human community to shape its future and sustain the significant processes of change that enables them to do so. These processes of change place a significant burden on managers who now are expected to embrace the change-orientated attributes that will give them the ability to cope with uncertainty and become leaders, innovators and risk takers (Caldwell, 2003). These changeorientated attributes refer to the competencies leaders require in times of change.

Over the years various studies focusing on leadership have included (Robbins, \& De Cenzo, 1998):

- Trait theories of leadership. These are theories that isolate personal characteristics that differentiate leaders from nonleaders;

- Behavioural theories of leadership. These are theories that isolate behaviours that differentiate effective leaders from ineffective leaders;

- Contingency theories of leadership. These theories focus on situational influences and the relationship between leadership style and effectiveness; and

- The modern schools of leadership which include:

- Transactional leadership. This approach (Aalitio-Marjosola \& Takala, 2000) refers to leaders who guide or motivate their followers toward established goals by clarifying role and task requirements. It focuses on middle and first-line management (Lussier, 1997) and is mostly associated with intellectual intelligence (Mussig, 2003);

- Transformational leadership. This approach is described as an approach that focuses on developing an appealing vision of the future (Eisenbach et al, 1999), providing strategic and motivational focus (Eisenbach et al, 1999) and appealing to the intrinsic motivation of followers and providing inspiration (Cardona, 2000). Furthermore, it has been described as an enriched form of transactional leadership (Cardona, 2000) that is associated with emotional intelligence (Sivanathan \& Fekken, 2002, Palmer et al, 2001 and Barling et al, 2000);

- Charismatic leadership is often used interchangeably with transformational leadership (Pawar, 2003). It is associated with inspiration and the ability to make radical changes to reach a goal (Lussier, 1997);

- Servant leadership focuses on the personal development of the followers (Stone et al, 2004) while placing service at 
its core (Russell \& Stone, 2002). It is said to be based on ethical and caring behaviour (Russell, 2001); and

- Transcendental leadership. This approach refers to leaders who recognise the spirituality that compels leaders to look beyond their own egos and to be more concerned about an internal development that transcends realities as defined by the environment (Sanders, Hopkins \& Geroy, 2003).

Bringing some of the thoughts around the modern schools of leadership together, Sanders et al (2003) developed a model that suggests that there are three structural levels of leadership accomplishment that are linked together along a hierarchical continuum namely transactional, transformational and transcendental. The continuum stretches from the lower positioning of the transactional leadership theory (which is likely to be associated with a relatively low sense of divine awareness) to the higher positioning of transcendental leadership (which is associated with a higher level of spirituality which mobilizes the individual toward meaningful or transcendental accomplishment and incorporates the leadership theories on the lower positions in the continuum).

Furthermore, the leadership abilities described under the different schools of leadership could broadly be divided into three categories. These are cognition, emotional and spiritual which have been coined by authors like Mussig (2003) who distinguishes between intellectual, spiritual and emotional intelligences and Tischler et al (2002) who distinguishes between $\mathrm{IQ}$, emotional intelligence and spiritual intelligence. The three main leadership schools can be associated with the following types of intelligence as outlined in Table 1 below.

TABLE 1

SCHOOLS OF LEADERSHIP AND INTELLIGENCE

\begin{tabular}{ll}
\hline Leadership School & Type of intelligence \\
\hline Transactional & Cognition/ Intellectual intelligence \\
Transformational & Emotional intelligence \\
Transcendental & Spiritual intelligence \\
\hline
\end{tabular}

For the purpose of this study, charismatic and servant leadership were clustered under transformational leadership, following the arguments of Sarros \& Santora (2001), Robbins \& Cenzo (1998) and Aaltio-Marjosola \& Takala (2000) in terms of charismatic leadership as well as the arguments of Stone et al (2004) in terms of servant leadership. This is due to the significant amount of overlap between these two approaches and transformational leadership.

It was concluded in this section that transformational leadership is an enriched transactional leadership and that transcendental leadership incorporates transactional, transformational, charismatic and servant leadership. It can therefore be argued that transformational leadership incorporates cognition and emotional intelligence and transcendental leadership incorporates cognition, emotional intelligence and spiritual intelligence. This is illustrated in Figure 1 below.

The above definitions and schools of leadership thought suggest that leaders must understand the roles they need to perform in situations of rapid change, be able to shape change-agile employees and understand that leadership is a strategic issue.

In this context Marquardt (2000) argues that it has become increasingly clear that the new century demands new kinds of leaders with new skills. He suggests that the skills that may have worked in a more stable, predictable environment will be inadequate in the new era of uncertainty and rapid change where it is difficult to define the problem and even more difficult to engineer possible solutions. The next section will therefore explore change as it relates to leadership.

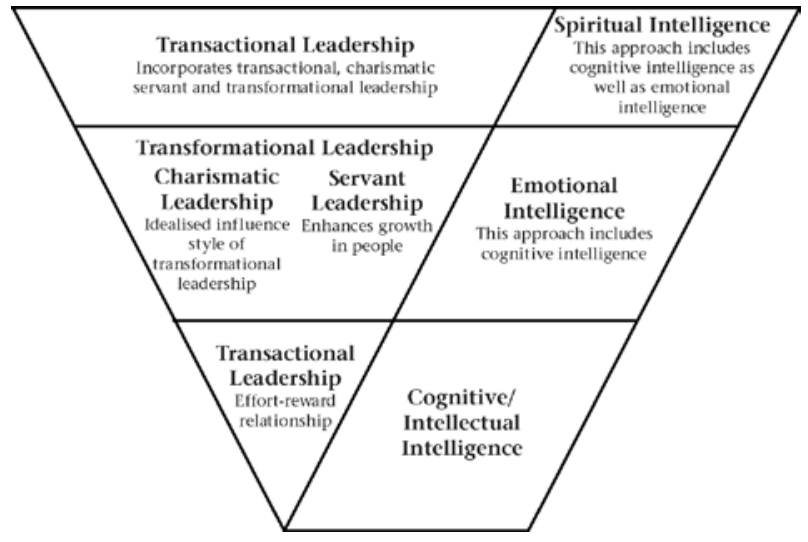

Figure 1: Schools of leadership and intelligence types

\section{Change}

Based on organisational and sociological definitions, Powell (2001, p 17) defines change as: "change ultimately is any activity that alters the current state within an organizational or sociological setting. The change activity can result in either positive or negative outcomes dependent upon many variables that occur prior to, during or after the change process. The initiation of the alteration of the current state can be a result of either internal or external influences that create the requirement, need or desire for the change activity". Powell further purports that change occurs as a result of an internal or external initiator that creates a requirement, need or desire for change based on the perception of managers or employees within an organisation. Similarly Valle (2002, p. 218) defines organisational change as: "a process of identification and implementation of new organizational routines and practices". This is illustrated in Figure 2 below.

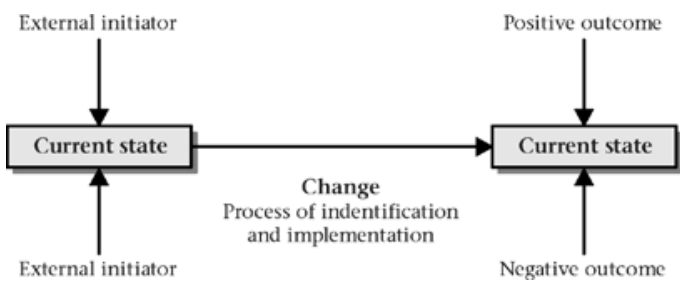

Figure 2: Change as a process

Furthermore, as organisations do not operate in isolation it is important for leaders to understand the context within which they operate. This context within which change should be understood includes society, the organisation as well as the individual.

\section{Society and change}

Toffler (1994) and Slabbert (1996) refer to the following eras in society:

- The stone age that was marked by human groups existing through hunting. This era was followed by a revolution that ushered in the agricultural age;

- The agricultural age featured tools of the hands and hoe (focus on human input). This era was followed by a revolution that ushered in the industrial age;

- The industrial age can be divided intro three major sectors:

- The manufacturing sector that saw the emergence of machines to do the work of men's hands (focus on mechanical input);

- The service sector with a focus on quality of personal service; and

- The knowledge sector marked by a technology wave providing an information boom that allowed people to gain more knowledge in a shorter time (focus on artificial intelligence) 
Political and social conflicts erupted in part because of the tools utilized throughout the waves (Toffler, 1994). Mankind moved from hunting (where power lay with those who had physical strength) to an era where the application of knowledge is needed to survive. Furthermore, mankind has moved from more stable environments characterized by the earlier eras to more chaotic environments in the later eras (Powell, 2001).

Society is the external environment within which organisations exist and its elements interact with each other to form some of the 'triggers' of change within an organisation (Senior, 1997).

\section{The Organisation and change}

Organisations, in other words formal business, started to dominate the landscape in the modern industrialized societies (Scott, 1981). They are systems that have been brought about by individuals in society, who have shared expectations and goals (Sullivan, 1999). They are made up of a collection of objects that interrelate and give rise to emergent properties in the system (Harrington et al, 1999) and are held together by relationships (Fairholm, 2004). Change in an organisation occurs when either an internal or external force causes an altering of the current state (Powell, 2001). The challenge that leaders in organisations face today is that the environmental contexts in which organisations exist are changing at an accelerating rate towards increasing complexity (Scott, 198).

In understanding the internal organisational context, three forces need to be considered, namely the leader, the followers and the situation (Kast \& Rosenzweig, 1985). A key element in the internal dynamics of the system is the leadership-followership relationship which is a dynamic relationship. During times of change the relationship may be altered as a result of a shift in expectations (Kast \& Rosenzweig, 1985).

\section{The Individual and change}

When organisations go through change there is a direct impact on the individuals in that organisation and their journey through that change can be quite complex. Employees who go through change are subject to a host of negative emotions which directly or indirectly have an enormous impact on their productivity in the organisations (Appelbaum \& Donia, 2000, Thornhill \& Gibbons, 1995 and Worrall et al, 2000). Furthermore, it is often forgotten that managers are employees too and that their reactions to change are just as human as every other worker's (Stuart, 1995). In this context Fairholm (2004) argues that understanding how people cope with change and transition allows the leader to remain confident and comfortable amid a variety of individual reactions.

\section{Change types}

There are two extreme types of circumstances against a continuum within which change occur. On the one hand there is a stable and predictable environment which calls for continuous or incremental change and on the other hand chaos and ambiguity which calls for transformation or frame-breaking change (Booysen \& Beaty, 1997, Senior, 1997, and Robbins, 1998). There is also a distinction made between structural/technical changes and behavioural changes in organisations (Waldersee \& Griffiths, 2004).

These changes can therefore be clustered as:

- Incremental structural/technical change;

- Frame-breaking structural/technical change;

- Incremental behavioural change; and

- Frame-breaking behavioural change.

In terms of the management or leadership of change, Senior (1997) suggests that leadership style and behaviour can vary according to the different organisational situations. The implication therefore is that different leadership approaches are needed for different types of change. Ghemawat et al (1999) point out that it is hard to mix and match across the extremes as different types of employees are required to deal with different changes. Furthermore, the roles leaders must perform presupposes that they must have the necessary competencies to perform those roles. The roles serve as a bridge between the leadership context and competencies (Veldsman, 1997). As the focus of this study is on leadership competencies, the next section will briefly explore competency, and also position it in relation to competence and capability.

\section{Competence, competency and capability}

In exploring the literature that includes authors like Veldsman (2002), Brown \& McCartney (2003), Rowe (1998), Stuart \& Lindsay (1997), Jaques (1998) and Morden (1997), it is clear that distinctions are made between competence, competency and capability. There seems to be a relationship between the three and that capability forms the platform on which competencies are built and on which competence is build in turn.

Veldsman (2002, p. 80) defines competence as "the ability and willingness to perform at the appropriate level as demanded by the context at a certain point in time, but also across time". It is a set of minimum requirements of those who are deemed to be especially effective. It is concerned with the ability to demonstrate what has been acquired with its root being the fact that it looks back into the past and gains its value and legality from its past time-value (Brown \& McCartney, 2003).

Rowe (1995, p. 12) defines competency as the behaviour by which competence is achieved i.e. a description of how people do it. Competencies therefore refer to the behaviours adopted in competent performance. Adding to Rowe's definition Stuart \& Lindsay (1997) purport that competencies are built up of smaller units or constituents which are termed elements of competencies. These elements are skills, knowledge, characteristics, traits and abilities.

Capability on the other hand looks forward to the fulfillment of potential and is not concerned with past performance or ability. It is therefore about the person's ability to learn how to perform tasks (which he or she does not have the knowledge or skill to perform at present) in the future (Brown \& McCartney, 2003). Capability is therefore more fluid and in a continual state of development.

For the purpose of this research the term competency, as applied to leadership, essentially therefore refers to the observable behaviour that a leader displays during various types of change.

\section{Research objectives}

The specific objectives of this study were:

- To describe change in terms of types of change, the impact of change and the need for leadership in times of change;

- To identify a set of competencies for each change type that leaders need to have in order to effectively lead people through change and uncertainty;

- To assess differences in the views of managers and their employees on the importance of each competency during each of the change types;

- To determine the degree to which managers are perceived to display the competencies; and

- To assess the differences in the views of managers and their employees on the degree to which the managers display the competencies identified.

The research was executed in the financial services sector in South Africa.

\section{Research hypotheses}

Based on the objectives of this study the following hypotheses were tested in the empirical phase of the research: 
- Hypothesis 1: There is a difference between the importance assigned to the competencies by the managers and the employees respectively; and

- Hypothesis 2: There is a difference in the perception of the managers and the perception of the employees on the degree to which the managers display the competencies.

\section{RESEARCH DESIGN}

\section{Research approach}

The strategy used is a Sequential Exploratory Strategy which is described by Creswell (2003) as a strategy which is conducted in two phases with the priority generally given to the first phase. It is characterized by an initial phase of qualitative data collection which is analysed and thereafter a phase of quantitative data collection and analysis is followed. In this case the quantitative data was used to apply the interpretation of the qualitative findings in the South African context. This is illustrated in Figure 3 below.

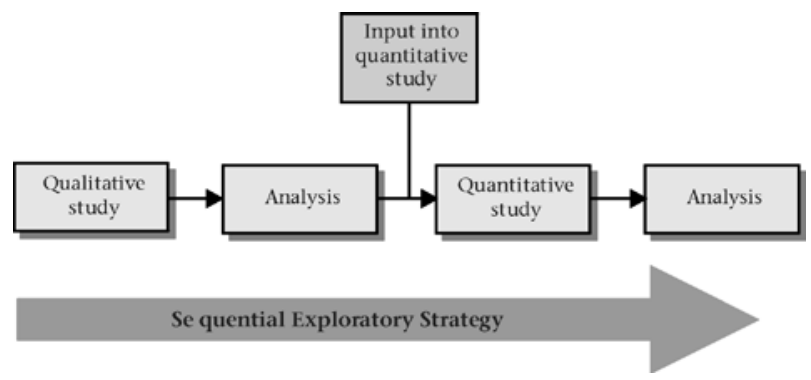

Figure 3: Sequential exploratory strategy used for the field research

\section{Research framework}

It is clear from the preceding sections that there is a distinct relationship between leadership, change and competency in that change calls for leadership and leadership is requires certain competencies.

This is illustrated in Figure 4 below.
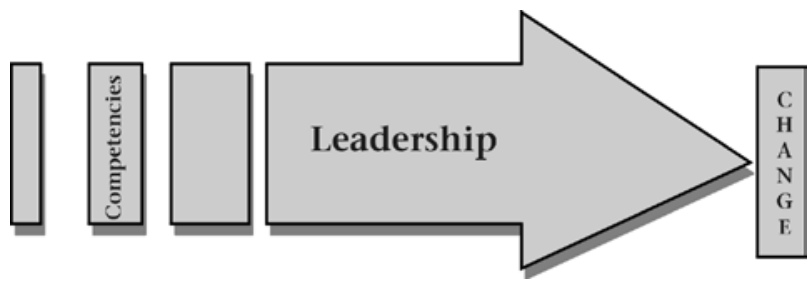

Figure 4: Relationship between leadership, change and competencies

In terms of creating a framework, the study focused on the four major change types identified, namely frame-breaking behavioural change, incremental behavioural change, frame-breaking structural/technical change and incremental structural/technical change. The study also focused particularly on the modern schools of leadership including transactional leadership, transformational leadership and transcendental leadership.

Having come to the conclusions around leadership, change and how they relate to each other in terms of competencies, Table 2 below combines these elements in one framework.
TABLE 2

LEADERSHIP, CHANGE AND COMPETENCY FRAMEWORK

\begin{tabular}{|c|c|c|c|c|}
\hline $\begin{array}{l}\text { School of } \\
\text { leadership }\end{array}$ & $\begin{array}{c}\text { Frame- } \\
\text { breaking } \\
\text { Behavioural } \\
\text { Change }\end{array}$ & $\begin{array}{c}\text { Incremental } \\
\text { Behavioural } \\
\text { Change }\end{array}$ & $\begin{array}{c}\text { Frame- } \\
\text { breaking } \\
\text { Structural/ } \\
\text { Technical } \\
\text { Change }\end{array}$ & $\begin{array}{c}\text { Incremental } \\
\text { Structural/ } \\
\text { Technical } \\
\text { Change }\end{array}$ \\
\hline
\end{tabular}

Transactional Competency 1 Competency 2 Competency 3 Competency n leadership

Transforma- Competency 1 Competency 2 Competency 3 Competency n tional

leadership

Transcen- Competency 1 Competency 2 Competency 3 Competency n dental

leadership

The framework suggests that the four major change types each comprise of a set of competencies that leaders require in order to lead people through that change type. The sets of competencies are related to certain leadership approaches and the framework therefore suggests that each change type may need a certain combination of leadership approaches. It could therefore be concluded that if the sets of competencies are determined and hence the combination of leadership approaches, leaders would be informed on what approach to adopt for each change type. Leaders could therefore also have a blueprint against which they can ascertain whether they have the competencies or not. This in turn would indicate how ready the leader is to lead people through each of the change types.

This framework formed the basis of the field study, which is expanded open in the following sections.

\section{Research methodology}

The research context

The study focused on one industry as the organisations within that industry are likely to experience the same challenges. The sector chosen for this study is the financial services sector as this sector has gone through some significant changes over the last few years. The study was limited to the South African context and therefore did not include the participating organisations' operations outside of the borders of South Africa.

\section{Participants}

Two samples of convenience were taken. An independent sample was taken for phase 1 in which leaders were interviewed. In contrast to the independent sample in phase 1 , a related or dependent sample of the managers and employees was taken for phase 2. In other words, inclusion of any manager by definition was also accompanied by inclusion of some of his or her employees. The three populations that formed part of the study are:

- Ten leaders in the financial services sector;

- Sixty middle managers in the financial services sector; and

- Seventy four employees reporting to the middle managers. 
Table 3 below depicts the profile of the ten leaders interviewed in phase 1.

TABLE 3

Profile of The interviewees

\begin{tabular}{lcl}
\hline \multicolumn{1}{c}{ Position } & $\begin{array}{c}\text { Years of managerial } \\
\text { experience }\end{array}$ & Demographic Profile \\
\hline Joint MD & 15 & White Male \\
CEO & 15 & African Male \\
Vice President & 30 & White Male \\
Executive President & 15 & African Male \\
Group Executive Director & 30 & African Male \\
$\begin{array}{l}\text { Executive Director: Sales, } \\
\text { Service and All Pay }\end{array}$ & 23 & Coloured Female \\
$\begin{array}{l}\text { Member of Executive } \\
\text { Management: Non-life } \\
\text { treaty }\end{array}$ & 24 & African Male \\
$\begin{array}{l}\text { Executive Director: } \\
\text { Strategic Initiatives }\end{array}$ & 5 & African Female \\
$\begin{array}{l}\text { Head of Public-Private } \\
\text { partnership SBU }\end{array}$ & 11 & African Male \\
\begin{tabular}{l} 
Deputy MD SA \\
\hline
\end{tabular} & 16 & African Male \\
\hline
\end{tabular}

Table 4 below depicts the biographical profile of the phase 2 respondents.

TABLE 4

BIOGRAPHICAL PROFILE OF THE RESPONDENTS

\begin{tabular}{llcc}
\hline & Profile & Managers & Employees \\
\hline Gender & Female & $37 \%$ & $64 \%$ \\
\multirow{3}{*}{ Race } & Male & $63 \%$ & $36 \%$ \\
& African & $10 \%$ & $18 \%$ \\
& Coloured & $7 \%$ & $17 \%$ \\
Age & Indian & $10 \%$ & $7 \%$ \\
& White & $73 \%$ & $58 \%$ \\
& $18-25$ & $0 \%$ & $1 \%$ \\
Level of & $26-35$ & $25 \%$ & $31 \%$ \\
qualification & Doctorate & $46 \%$ & $46 \%$ \\
& Masters & $22 \%$ & $15 \%$ \\
& Ab-55 & $7 \%$ & $7 \%$ \\
& Graduate & $0 \%$ & $1 \%$ \\
& Matric & $27 \%$ & $8 \%$ \\
& Grade 10 or less & $43 \%$ & $39 \%$ \\
& & $30 \%$ & $49 \%$ \\
\hline
\end{tabular}

\section{Measuring instruments}

For the quantitative phase of the study, questionnaires were designed based on the list of competencies created for each change type. This list of competencies was a product of the interview process undergone in phase one. The objective of this phase was to determine the perceptions of both the managers and employees on:

- The importance of each competency in times of change; and

- To what degree those competencies are displayed by the managers during times of change.

The same list of competencies was presented to managers as well as employees, but each with a different objective.
Managers were asked to assess themselves against the list of competencies as well as rate the importance of that competency. Employees were asked to assess their managers against the list of competencies as well as rate the importance of each competency. The same rating scales were used in both questionnaires.

The rating of the self-assessment will be on a scale of 1 to 4 ranging from:

- 1 being "Do not have this competency at all"

- 2 being "Displays this competency some of the time in change situations"

- 3 being "Displays this competency most of the time in change situations"

- 4 being "Displays this competency all of the time in change situations".

The rating of the importance of each competency will be on a scale of 1 to 4 , ranging from:

- 1 being "Not important at all"

- 2 being "Somewhat important"

- 3 being "Important"

- 4 being "Very important"

\section{Research procedure}

The procedure followed in phase one was that of faceto-face, unstructured one-on-one in-person interviews. The participants were asked to identify competencies that were required to handle four change types, namely frame-breaking behavioural change, incremental behavioural change frame-breaking structural/technical change and incremental structural/technical change. Competencies required for the handling of change were linked to the four change types on the basis of consensus. The consensus responses of the leaders were listed and used as a base for questionnaire design.

Once the lists of competencies had been established as an output of the qualitative part of the study, a questionnaire was drawn up and completed in phase two by managers and employees reporting to those managers. Both groups were asked to rate the importance of each competency as well as to indicate the degree to which they believed the managers displayed those competencies. The assistance of Human Resource Departments of selected organisations was elicited in the provision of respondents and collection of data. The questionnaires were completed electronically and e-mailed to the researcher.

\section{Statistical analysis}

In analyzing the data the following approaches were used:

- Simple descriptive analysis based on cross-tabulation with an interpretation done in terms of percentages. Some of these interpretations are visually displayed using bar charts;

- Chi-squared analyses were used to test for differences between the managers and employees respectively. In cases where the sample size was not sufficient for ordinary chi-squared analysis, the Fisher's Exact test was utilized;

- A reliability test was performed on the competency part of the questionnaire;

- Factor analysis was used to identify the dimensions of the competency part of the questionnaire;

- Analysis of variance (ANOVA) was used to determine the significance of differences between the mean scores of managers and employees respectively on the various dimensions of the questionnaire; and

- Where ANOVA's could not be used, Levene's tests were used to test for significance of differences. 


\section{RESULTS}

\section{Phase 1}

Every one of the leaders interviewed in the qualitative part of the field study was asked to provide a list of competencies for each change type, which they believe are required to successfully lead people through that change. These lists were compared and only the competencies mentioned by at least $50 \%$ of the leaders, for each change type, were included in the final lists. These competencies are listed in Table 5 below.

This table includes the leadership schools to which each of the competencies are related. From that information the following conclusions can therefore be drawn for the four change types:

- Leading people through frame-breaking behavioural change requires a combination of transformational and transcendental leadership approaches;

- Leading people through incremental behavioural change requires a combination of transformational and transcendental leadership approaches;

- Leading people through frame-breaking structural/ technical change requires a combination of transactional, transformational and transcendental leadership approaches; and

- Leading people through incremental structural/technical change requires a combination of transactional, transformational and transcendental leadership approaches.

These conclusions can further be summarised in that:

- Behavioural change requires a combination of transformational and transcendental leadership approaches; and

- Structural/technical change requires a combination of transactional, transformational and transcendental leadership approaches.

It is important to note that all four change types require a transcendental leadership approach, which has been classified as the highest level on the leadership hierarchy as well as incorporating the lower level leadership approaches.

TABLE 5

SCHOOLS OF LEADERSHIP, COMPETENCIES AND CHANGE TYPES

\begin{tabular}{llcccc}
\hline $\begin{array}{l}\text { School of } \\
\text { leadership }\end{array}$ & $\begin{array}{l}\text { Competen- } \\
\text { cies }\end{array}$ & $\begin{array}{c}\text { Frame- } \\
\text { breaking } \\
\text { Beha- } \\
\text { vioural } \\
\text { Change }\end{array}$ & $\begin{array}{c}\text { Incre- } \\
\text { mental } \\
\text { Beha- } \\
\text { vioural } \\
\text { Change }\end{array}$ & $\begin{array}{c}\text { Frame- } \\
\text { breaking } \\
\text { Ttructural// } \\
\text { Change } \\
\text { Changlical }\end{array}$ & $\begin{array}{c}\text { Incre- } \\
\text { mental } \\
\text { Structural/ } \\
\text { Chnical }\end{array}$ \\
\hline $\begin{array}{l}\text { Transact- } \\
\text { ional } \\
\text { leadership }\end{array}$ & $\begin{array}{l}\text { Ability to } \\
\text { execute the } \\
\text { vision }\end{array}$ & & & $\mathrm{X}$ \\
& $\begin{array}{l}\text { Have the } \\
\text { relevant } \\
\text { technical } \\
\text { skills with an } \\
\text { understanding } \\
\text { of the core } \\
\text { business. }\end{array}$ & & & \\
\end{tabular}

\begin{tabular}{|c|c|c|c|c|c|}
\hline \multirow[t]{7}{*}{$\begin{array}{l}\text { Transform- } \\
\text { ational } \\
\text { leadership }\end{array}$} & $\begin{array}{l}\text { Ability to } \\
\text { create a clear } \\
\text { vision }\end{array}$ & $X$ & $\mathrm{X}$ & $X$ & $X$ \\
\hline & $\begin{array}{l}\text { Ability to } \\
\text { communicate } \\
\text { until } \\
\text { understood }\end{array}$ & $X$ & $X$ & & \\
\hline & $\begin{array}{l}\text { Ability to get } \\
\text { buy-in from } \\
\text { all levels } \\
\text { of staff by } \\
\text { creating a } \\
\text { willingness } \\
\text { in people to } \\
\text { change }\end{array}$ & $X$ & $X$ & & $X$ \\
\hline & $\begin{array}{l}\text { Ability to lead } \\
\text { by example, } \\
\text { in other words } \\
\text { walk the talk }\end{array}$ & $X$ & & & \\
\hline & $\begin{array}{l}\text { Open minded, } \\
\text { flexible i.e. } \\
\text { willing to } \\
\text { change }\end{array}$ & & $X$ & $X$ & \\
\hline & $\begin{array}{l}\text { Empowering } \\
\text { people by } \\
\text { creating a } \\
\text { culture of } \\
\text { participation } \\
\text { that makes } \\
\text { people feel } \\
\text { that they are } \\
\text { part of the } \\
\text { process }\end{array}$ & $X$ & & & \\
\hline & $\begin{array}{l}\text { Lead with } \\
\text { empathy. } \\
\text { Ability to } \\
\text { recognize that } \\
\text { people react } \\
\text { to change } \\
\text { differently, } \\
\text { being attuned } \\
\text { to people's } \\
\text { feelings, being } \\
\text { sensitive to } \\
\text { peoples' needs }\end{array}$ & $X$ & $X$ & $X$ & $X$ \\
\hline $\begin{array}{l}\text { Transcen- } \\
\text { dental } \\
\text { leadership }\end{array}$ & $\begin{array}{l}\text { Ability } \\
\text { to build } \\
\text { credibility } \\
\text { with people } \\
\text { through } \\
\text { integrity, } \\
\text { consistency, } \\
\text { transparency }\end{array}$ & $X$ & X & $X$ & $X$ \\
\hline
\end{tabular}

\section{Phase 2}

The respondents were asked to identify the types of change that they had experienced in the last two years. Their reported experiences are summarized in Table 6 below.

It is clear that:

- Fairly high percentages in both groups reported to have not experienced the various change types;

- The change type that has the highest counts, in terms of respondents reporting that they have experienced it, is framebreaking behavioural change; and

- The change type that has the lowest counts, in terms of respondents reporting that they have experienced it, is incremental structural/technical change. 
TABLE 6

CHANGE TYPES EXPERIENCED BY THE MANAGERS AND THE EMPLOYEES

\begin{tabular}{|c|c|c|c|}
\hline \multicolumn{2}{|c|}{$\begin{array}{l}\text { Change types experienced in the last two } \\
\text { years }\end{array}$} & \multirow{2}{*}{$\begin{array}{c}\text { Managers } \\
65 \%\end{array}$} & \multirow{2}{*}{$\begin{array}{c}\text { Employees } \\
57 \%\end{array}$} \\
\hline $\begin{array}{l}\text { Frame-breaking } \\
\text { behavioural change }\end{array}$ & $\begin{array}{l}\text { Have experienced this } \\
\text { change type }\end{array}$ & & \\
\hline & $\begin{array}{l}\text { Have NOT experienced this } \\
\text { change type }\end{array}$ & $35 \%$ & $43 \%$ \\
\hline \multirow{2}{*}{$\begin{array}{l}\text { Frame-breaking } \\
\text { structural/technical } \\
\text { change }\end{array}$} & $\begin{array}{l}\text { Have experienced this } \\
\text { change type }\end{array}$ & $62 \%$ & $57 \%$ \\
\hline & $\begin{array}{l}\text { Have NOT experienced this } \\
\text { change type }\end{array}$ & $38 \%$ & $43 \%$ \\
\hline \multirow[t]{2}{*}{$\begin{array}{l}\text { Incremental } \\
\text { behavioural change }\end{array}$} & $\begin{array}{l}\text { Have experienced this } \\
\text { change type }\end{array}$ & $43 \%$ & $55 \%$ \\
\hline & $\begin{array}{l}\text { Have NOT experienced this } \\
\text { change type }\end{array}$ & $57 \%$ & $45 \%$ \\
\hline \multirow{2}{*}{$\begin{array}{l}\text { Incremental } \\
\text { structural/technical } \\
\text { change }\end{array}$} & $\begin{array}{l}\text { Have experienced this } \\
\text { change type }\end{array}$ & $47 \%$ & $42 \%$ \\
\hline & $\begin{array}{l}\text { Have NOT experienced this } \\
\text { change type }\end{array}$ & $53 \%$ & $58 \%$ \\
\hline
\end{tabular}

Degree to which managers display the competencies

In the case of fifty percent of the competencies there is a statistically significant difference in distribution between the views of the managers and that of the employees, on the degree to which the managers display the competencies. For these competencies the research hypothesis has been accepted. In the case of the other fifty percent the research hypothesis was rejected as there was no difference in the distributions of the views of the managers and the views of the employees. Table 7 below summarizes the views of the managers and the employees in terms of the degree to which they believe that the managers display the competencies in times of change. The competencies where a statistically significant difference was found between the two groups are marked with an asterix $\left({ }^{*}\right)$.

\section{Importance assigned to the competencies}

The managers and employees who responded to the survey confirmed the importance of the competencies identified by the leaders as being important in times of change. The leaders who participated in the qualitative phase of the study reported that different combinations of the competencies are needed for the different types of change. The respondents did not however confirm that different combinations of leadership competencies are needed in different types of change. To the contrary, the data suggests that both the managers and the employees feel that all the competencies are important for all the change types.

The only competency where a statistically significant difference between the two groups was found is "Ability to lead by example, in other words walk the talk". The managers placed a higher degree of importance on this competency with eighty two percent seeing it as very important as opposed to only sixty five percent of employees rating it as very important. The research hypothesis has therefore been accepted for this competency.
TABLE 7

COMPARING THE PERCEPTIONS OF THE MANAGERS AND THE EMPLOYEES ON THE DEGREE TO WHICH THE MANAGERS DISPLAY THE COMPETENCIES

\begin{tabular}{|c|c|c|c|c|c|c|c|c|}
\hline \multirow{3}{*}{$\begin{array}{l}\text { Competency } \\
\begin{array}{l}\text { Ability to create a clear } \\
\text { vision }\end{array}\end{array}$} & \multicolumn{2}{|c|}{$\begin{array}{l}\text { Does not } \\
\text { have this } \\
\text { compe- } \\
\text { tency at } \\
\text { all }\end{array}$} & \multicolumn{2}{|c|}{$\begin{array}{l}\text { Displays } \\
\text { this } \\
\text { compe- } \\
\text { tency } \\
\text { some of } \\
\text { the time }\end{array}$} & \multicolumn{2}{|c|}{$\begin{array}{l}\text { Displays } \\
\text { this } \\
\text { compe- } \\
\text { tency } \\
\text { most of } \\
\text { the time }\end{array}$} & \multicolumn{2}{|c|}{$\begin{array}{l}\text { Displays } \\
\text { this } \\
\text { compe- } \\
\text { tency all } \\
\text { of the } \\
\text { time }\end{array}$} \\
\hline & $\mathrm{M}$ & $\mathrm{E}$ & M & E & M & E & M & $\mathrm{E}$ \\
\hline & $2 \%$ & $4 \%$ & $20 \%$ & $18 \%$ & $61 \%$ & $51 \%$ & $17 \%$ & $27 \%$ \\
\hline $\begin{array}{l}\text { Ability to execute the } \\
\text { vision }\end{array}$ & $0 \%$ & $3 \%$ & $8 \%$ & $22 \%$ & $67 \%$ & $47 \%$ & $25 \%$ & $28 \%$ \\
\hline $\begin{array}{l}\text { Ability to communicate } \\
\text { until understood }\end{array}$ & $0 \%$ & $4 \%$ & $13 \%$ & $14 \%$ & $37 \%$ & $47 \%$ & $50 \%$ & $35 \%$ \\
\hline $\begin{array}{l}\text { Ability to get buy-in } \\
\text { from all levels of staff by } \\
\text { creating a willingness in } \\
\text { people to change. }\end{array}$ & $0 \%$ & $5 \%$ & $15 \%$ & $22 \%$ & $62 \%$ & $47 \%$ & $23 \%$ & $26 \%$ \\
\hline $\begin{array}{l}{ }^{*} \text { Ability to build credibility } \\
\text { with people through } \\
\text { integrity, consistency, } \\
\text { transparency }\end{array}$ & $0 \%$ & $3 \%$ & $3 \%$ & $16 \%$ & $45 \%$ & $43 \%$ & $52 \%$ & $38 \%$ \\
\hline $\begin{array}{l}\text { *Ability to lead by } \\
\text { example, in other words } \\
\text { walk the talk }\end{array}$ & $0 \%$ & $3 \%$ & $0 \%$ & $20 \%$ & $45 \%$ & $46 \%$ & $55 \%$ & $31 \%$ \\
\hline $\begin{array}{l}\text { * Open minded, flexible i.e. } \\
\text { willing to change }\end{array}$ & $0 \%$ & $3 \%$ & $3 \%$ & $24 \%$ & $49 \%$ & $41 \%$ & $48 \%$ & $32 \%$ \\
\hline $\begin{array}{l}{ }^{*} \text { Empowering people } \\
\text { by creating a culture of } \\
\text { participation that makes } \\
\text { people feel that they are } \\
\text { part of the process }\end{array}$ & $0 \%$ & $4 \%$ & $12 \%$ & $26 \%$ & $55 \%$ & $27 \%$ & $33 \%$ & $43 \%$ \\
\hline $\begin{array}{l}\text { *Lead with empathy. } \\
\text { Ability to recognize that } \\
\text { people react to change } \\
\text { differently, being attuned } \\
\text { to people's feelings, being } \\
\text { sensitive to people's needs. }\end{array}$ & $0 \%$ & $4 \%$ & $17 \%$ & $28 \%$ & $38 \%$ & $38 \%$ & $45 \%$ & $30 \%$ \\
\hline $\begin{array}{l}\text { Have the relevant } \\
\text { technical skills with an } \\
\text { understanding of the core } \\
\text { business }\end{array}$ & $0 \%$ & $1 \%$ & $5 \%$ & $14 \%$ & $47 \%$ & $41 \%$ & $48 \%$ & $44 \%$ \\
\hline
\end{tabular}

$\mathbf{M}=$ Manager

$\mathbf{E}=$ Employee

\section{DISCUSSION}

The complex research design of this study required a comprehensive review of available literature. This review covered: (i) the modern schools of leadership; (ii) change in its various levels of context; and (iii) leadership competencies at basic, potential and proven levels. As South Africa is undoubtedly part of the global world, challenges to cope with complexity, change and uncertainty that confront leaders elsewhere in the world are the same ones that South African business leaders need to tackle head-on. The main areas explored in this study are:

- Change in organizations require leadership;

- Leadership requires competencies; and

- Different change types may require different competencies.

Four types of change were identified in the literature review. The fact that high percentages in both groups reported that they had not experienced the various change types in the last two years raises the following questions:

- Is the rate of change experienced by organisations being overestimated;

- Is the financial sector more stable than other sectors; or

- Have people become so used to change that they are longer conscious of it? 
Furthermore the differences in the percentages representing the experiences of the managers as opposed to those of the employees reinforce Beugelsdijk et al's (2002:325) argument that organisational change may have different interpretations. They found in their study at Heineken Inc that many lower level employees in the organisation described the organisational changes as being completely incremental, while senior managers tended to make sense of the changes as being discontinuous and revolutionary.

Another important finding was that although both the leaders who participated in the qualitative part of the study as well as the respondents in the quantitative part of the study rated all the competencies as important, it seems that there are two opposing views regarding the competencies:

- Confirming the conclusions in the literature review, the leaders in the qualitative part of the study concluded that the different change types require different sets of competencies; while

- The managers and employees in the quantitative part of the study indicated that all ten competencies are important for all the different change types.

\section{Conclusions}

From the results it is clear that all change types call for transcendental leadership competence, whether or not all the competencies are needed for all the change types or whether the different change types each needs its own set of competencies.

The conclusion was drawn earlier that transcendental leadership includes transformational leadership as well as transactional leadership. A leader in an organisation that operates in a constantly changing environment should therefore have the ability to apply transactional, transformational as well as transcendental leadership approaches. In other words such a leader would need to have a combination of cognitive, emotional and spiritual intelligence. It is important to note that the results of this study strongly suggest that the application of both emotional and spiritual intelligence is needed across all four of the major change types. This finding reinforces the fact that in recent times there has been a rising call to include spirituality in the workplace (Tischler, 1999). Up until very recently literature focusing in transformational leadership has concentrated on the individual, the group and the organisation, a step forward from a limited focus in leadership studies on initiating structure and consideration (Chakraborty \& Chakraborty, 2004). The new era organisation is however calling for leaders who can transcend beyond self, consumerist business and divisive politics (ibid).

\section{Practical implications of the study}

The contribution of this study can be found on at least two levels. In the first instance, the methodology and instruments used were proven to be useful in research on leadership and leadership competencies. Secondly, and arguably even more importantly, the results that also shows some departure from the mainstream literature opens up interesting possibilities for further research into the topic.

Leaders face the challenge of having to deal with the complexity of change, the uncertainty it produces, the unpredictability that accompanies it as well as the inertia in their organisations. It could therefore be concluded that in applying the framework created in this study, leaders would be informed on what approach to adopt for each change type. Leaders could therefore also have a blueprint against which they can ascertain whether they have the competencies or not. This in turn would indicate how ready the leader is to lead people through each of the change types.

\section{Limitations of the study}

The following areas are potential limitations within the study as well as areas where further research could be done outside of this study:
- The study focused on the financial services industry. Further studies could be conducted in other industries in order to create comparisons and to gain a more comprehensive view of the South African manager's abilities to lead people through change and uncertainty;

- The field study only focused on the employee aspect of change management as the focus was on leading employees through change and uncertainty. Further studies that would incorporate other dimensions in the organisation such as the customers and production may reveal additional sets of competencies;

- Within the South African context the issue of differences in gender and race are pertinent points of discussion. Comparing views in terms of managerial ability between gender groups and between race groups may reveal a different set of results;

- Comparing views across generational groups may also reveal important results; and

- High percentages in both groups reported that they had not experienced the various change types even though the literature suggests that this sector has experienced quite a number of changes in the last few years. How people experience change and whether constant change eventually makes people oblivious to change may be another area for further study.

\section{Conclusion}

The transcendental leader leaps forward in the evolutionary journey towards a leadership approach that is concerned with the people themselves, and tries to contribute to their personal development. This has far reaching implications for organisations in terms of the approach taken when managers are trained, or even at the point of recruitment. Clearly the organisation should look beyond cognitive intelligence and even emotional intelligence. The organisation that looks for leaders who can successfully lead people through change and uncertainty should now look for spiritual intelligence in addition to cognitive and emotional intelligence.

\section{REFERENCES}

Aaltio-Marjosola, I., Takala, T. (2000). Charismatic leadership, manipulation and the complexity of organizational life. Journal of Workplace Learning: Employee Counselling Today, $12,(4), 146-158$.

Appelbaum, S.H, Donia, M. (2000). The realistic downsizing preview: a management intervention in the prevention of survivor syndrome (part 1). Career Development International, 5 (7) 333-350.

Barling, J., Slater, F., Kelloway, E. (2000). Transformational leadership and emotional intelligence: an exploratory study. Leadership \& Organisation Development Journal, 21, (3), 157161.

Beugelsdijk, S., Slangen, A., van Herpen, M. (2002). Shapes of organisational change: the case of Heineken Inc. Journal of Organisational Change Management, 15, (3), 311-326.

Booysen, L. \& Beaty, D. (1997). Linking transformation and change leadership in South Africa: a review of principles and practices. SBL Research Review, 1, (2), 9-18.

Brown, R.B., McCartney, S. (2003). Let's have some capatence here. Education + Training, 45, 91), 7-12.

Caldwell, R. (2003). Change leaders and change managers: different or complementary? Leadership \& Organisation Development Journal, 24, (5), 285-293.

Cardona,P. (2000). Transcendental leadership. The Leadership and Organisation Development Journal, 21, (4), 204.

Chakraborty, S.K., Chakraborty, D. (2004). The transformed leader and spiritual psychology: a few insights. Journal of Organizational Change Management, 17, (2), 194-210.

Creswell,J.W. (2003). Research Design: Qualitative, Quantitative and Mixed Methods approaches. USA: Sage Publications, Inc. 
Eisenbach, R., Watson, K., Pillai, R. (1999). Transformational leadership in the context of organizational change. Journal of Organizational Change Management, 12, (2), 80-89.

Fairholm, M.R. (2004). A new sciences outline for leadership development. Leadership and Organisation Development Journal, 25, (4), 369-383.

French, R. (2001). "Negative capability": managing the confusing uncertainties of change. Journal of Organisational Change Management, 14, (5), 480-492.

Ghemawat, P, Collis, D.J Pisano, G.P., Rivkin, J.W. (1999) Strategy and the Business Landscape. USA: Addison-Wesley Longman, Inc.

Grieves, J. (2000). Navigating change into the new millennium: themes and issues for the learning organisation. The Learning Organisation, 7, (2), 54-74.

Harrington, H.J., Carr, J.J., Reid, R.P. (1999). What's this "systems stuff", anyhow? The TQM Magazine, 11, (1), 54-57.

Higgs, M. (2003). How can we make sense of leadership in the $21^{\text {st }}$ century? Leadership \& Organisation Development Journal, 24, (5), 273-284.

Jaques, E. (1998). Requisite Organisation. A total system for effective managerial organization and managerial leadership for the $21^{\text {st }}$ century. USA: Casin Hall \& Co. Publishers.

Kast, F.E., Rosenzweig, J.E. (1985). Organisation and Management. A Systems and Contingency Approach. Singapore: McGrawHill, Inc.

Kets de Vries, M. (2001). The leadership mystique. A user's manual for the human enterprise. Great Britain: Pearson Education Ltd.

Kotter, J. (1996). Leading Change. Boston: Harvard Business School Press.

Lussier,R.N. (1997). Management: concepts, applications and skills development. USA: International Thomson Publishing.

Marquardt, M.J. (2000) Action learning and leadership. The Learning Organisation, 7, (5), 233-241.

Morden, T. (1997). Leadership as competence. Management Decision, 35, (7), 519-526.

Mussig, D.J. (2003). A research and skills training framework for values-driven leadership. Journal of European Industrial Training, 27, (2/3/4), 73-79.

Palmer, B., Walls, M., Burgess, Z., Stough, C. (2001). Emotional intelligence and effective leadership. Leadership \& Organization Development Journal, 22, (1), 5-10.

Pawar,B.S. (2003). Central conceptual issues in transformational leadership research. Leadership and Organisation Development Journal, 24, (7), 399.

Powell, W.R. Jr (2001). Theories of societal development and cross-cultural aspects of organisational change. Futurics. St. Paul, 25 (1/2), 1-26.

Rabey, G.P. (2006). Response to uncertainty. Team Performance Management, 12, (3/4), 77-81.

Robbins, S.P. (1998). Organizational behaviour. Concepts, Controversies, Applications. USA: Prentice Hall International, Inc.

Robbins, S.P \& De Cenzo, D.A. (1998). Fundamentals of Management. USA:Prentice Hall International, Inc.

Rowe, C. (1995). Clarifying the use of competence and competency models in recruitment, assessment and staff development. Industrial and Commercial Training, 27, (11), 12-17.

Russell, R.F. (2001). The role of values in servant leadership. Leadership and Organisation Development Journal, 22, (1), 76-84.
Russell, R.F., Stone, A.G. (2002). A review of servant leadership attributes: developing a practical model. Leadership \& Organization Development Journal, 23, (3), 145-157.

Sanders III, J.E., Hopkins, W.E., Geroy, G.D. (2003). From transactional to transcendental: toward an integrated theory of leadership. The Journal of Leadership Studies, 9, (4), 21-31.

Sarros, J.C., Santora, J.C. (2001). The transformational transactional leadership model in practice. Leadership \& Organization Development Journal, 22, (8), 383-394.

Scott, W.R (1981). Organisations. Rational, Natural and Open Systems. USA: Prentice Hall, Inc.

Senge, P. et al (1999). The Dance of change. The challenges to sustaining momentum in learning organizations. USA: Doubleday

Senior,B. (2004). Organizational Change, 7. Great Britain: Pearson Education Limited.

Siegel, W., et al (1996). Understanding the management of change. An overview of manager's perspectives and assumptions in the 1990s. Journal of Organisational Change Management, 9, (6), 54-80.

Sivanathan, N., Fekken, G.C. (2002). Emotional intelligence, moral reasoning and transformational leadership. Leadership \& Organization Development Journal, 23, (4), 198-204.

Slabbert, A (1996). Capitalism at the Crossroads. International Journal of Social Economics. 23, (9) 41-50.

Stone, G.A., Russell, R.F., Patterson, K. (2004) Transformational versus servant leadership: a difference in leader focus. Leadership \& Organization Development Journal, 25, 94), 349-361.

Stuart, R. (1995). Experiencing organisational change: triggers, processes and outcomes of change journeys. Personnel Review, 24, (2), 3-88.

Stuart, R., Lindsay, P. (1997). Beyond the frame of management competenc(i)es: towards a contextually embedded framework of managerial competence in organizations. Journal of European Industrial Training, 21, (1), 26-33.

Sullivan, T.J. (1999). Leading people in a chaotic world. Journal of Educational Administration, 37 (5), 408-423.

Tischler, L. (1999). The growing interest in spirituality in business. Journal of Organizational Change Managent, 12, (4), 273-280.

Tischler, L., Biberman, J., McKeage, R. (2002). Linking emotional intelligence, spirituality and workplace performance. Journal of Managerial Psychology, 17, (3), 203-218.

Toffler, A. (1994). Creating a new civilization: The politics of the third wave.

Thornhill, A., Gibbons, A. (1995). The positive management of redundancy survivors: issues and lessons. Employee Counselling Today, 7, (3), 5-12.

Valle, Economia y Administracion de Empresas, Falcultad de CCEE y Empresariales, Universidad de Valledolid, Valladolid, Spain. (2002) The phenomenon of organizational evolution: a model for analysis. Leadership and Organisation Development Journal, 23, (4), 215-227.

Veldsman, T.H. ( 2002). Into the people effectiveness arena. South Africa: Knowledge Resources (Pty) Ltd.

Waldersee, R., Griffiths, A. (2004) Implementing change: matching implementation methods and change type. Leadership and Organization Development Journal 25, (5), 424-434.

Worrall, L., Campbell, F., Cooper, C. (2000). Surviving redundancy: the perceptions of UK managers. Journal of Managerial Psychology, 15, (5), 460-476. 